\title{
Prognostic value of long noncoding RNAs in gastric cancer: a meta-analysis
}

This article was published in the following Dove Press journal: OncoTargets and Therapy

\author{
Song Gao' \\ Zhi-Ying Zhao ${ }^{2}$ \\ Rong Wu' \\ Yue Zhang ${ }^{3}$ \\ Zhen-Yong Zhang'
}

'The Second Department of Clinical Oncology, Shengjing Hospital of China Medical University, Shenyang, Liaoning, People's Republic of China; ${ }^{2}$ Division of Clinical Epidemiology, Shengjing Hospital of China Medical University, Shenyang, Liaoning, People's Republic of China; ${ }^{3}$ First Clinical Medical College, Shandong University of Traditional Chinese Medicine, Jinan, Shandong, People's Republic of China

Correspondence: Yue Zhang First Clinical Medical College, Shandong University of Traditional Chinese Medicine, No 16, 369 Jingshi Road, Lixia District, Jinan, Shandong, People's Republic of China

Tel +8653 I 686I 6426

Fax +86 53I 82602948

Email zhangyue08II@hotmail.com

Zhen-Yong Zhang

The Second Department of Clinical Oncology, Shengjing Hospital of China Medical University, No 39 Huaxiang

Road, Tiexi District, Shenyang, Liaoning,

People's Republic of China

Tel +86 I89 40257577

Fax +862423842568

Email zhangzy@sj-hospital.org
Background: In the last few years, accumulating evidence has indicated that numerous long noncoding RNAs (IncRNAs) are abnormally expressed in gastric cancer (GC) and are associated with the survival of GC patients. This study aimed to conduct a meta-analysis on 19 lncRNAs (AFAP1 antisense RNA 1 [AFAP1-AS1], CDKN2B antisense RNA 1 [ANRIL], cancer susceptibility 15 [CASC15], colon cancer associated transcript 2 [CCAT2], gastric adenocarcinoma associated, positive CD44 regulator, long intergenic noncoding RNA [GAPLINC], H19, imprinted maternally expressed transcript [H19], HOX transcript antisense RNA [HOTAIR], HOXA distal transcript antisense RNA [HOTTIP], long intergenic non-protein coding RNA 673 [LINC00673], metastasis-associated lung adenocarcinoma transcript 1 [MALAT1], maternally expressed 3 [MEG3], promoter of CDKN1A antisense DNA damage activated RNA [PANDAR], Pvt1 oncogene [PVT1], SOX2 overlapping transcript [Sox2ot], SPRY4 intronic transcript 1 [SPRY4-IT1], urothelial cancer associated 1 [UCA1], X inactive specific transcript [XIST], ZEB1 antisense RNA 1 [ZEB1-AS1] and ZNFX1 antisense RNA 1 [ZFAS1]) to systematically estimate their prognostic value in GC.

Methods: The qualified literature was systematically searched in PubMed, Web of Science, Embase and Cochrane Database of Systematic Reviews (up to March 16, 2018), and one metaanalysis relating to the relationship between lncRNA expression and overall survival (OS) of GC patients was performed. The only evaluation criterion of survival results was OS.

Results: A total of 6,095 GC patients and 19 lncRNAs from 51 articles were included in the present study. Among the listed 19 lncRNAs, 18 lncRNAs (other than SPRY4-IT1) showed a significantly prognostic value $(P<0.05)$.

Conclusion: This meta-analysis suggested that the abnormally expressed lncRNAs (AFAP1AS1, ANRIL, CASC15, CCAT2, GAPLINC, H19, HOTAIR, HOTTIP, LINC00673, MALAT1, MEG3, PANDAR, PVT1, Sox2ot, UCA1, XIST, ZEB1-AS1 and ZFAS1) were significantly associated with the survival of GC patients, among which AFAP1-AS1, CCAT2, LINC00673, PANDAR, PVT1, Sox2ot, ZEB1-AS1 and ZFAS1 were strong candidates in predicting the prognosis of GC patients.

Keywords: long noncoding RNA, gastric cancer, prognosis, meta-analysis

\section{Introduction}

In the last few years, accumulating evidence has indicated that numerous long noncoding RNAs (lncRNAs) are abnormally expressed in gastric cancer (GC) and are associated with the survival of GC patients. ${ }^{1-113} \mathrm{GC}$ is the fourth most diagnosed tumor type and the third most common origin of tumor-related death all over the world. ${ }^{114,115}$ Although the incidence and mortality of GC are declining, >24,590 individuals are diagnosed with GC per year, of which 10,720 die from GC in the USA. ${ }^{116}$ Although diagnosis and treatment strategies have been improved, the number of surviving cases remains low, since diagnosis 
often occurs in the late stages. ${ }^{116,117}$ Thus, the molecular characteristics about the carcinogenesis of GC and the recognition of new biomarkers for GC are urgently needed.

lncRNA is a new type of noncoding RNA that has a length of $>200$ nucleotides (nt) and lacks important open reading frameworks and can be divided into five main categories (sense, antisense, bidirectional, intronic and intergenic). ${ }^{118}$ Abundant evidence has demonstrated that lncRNAs play significant regulatory roles in tumor biology via various mechanisms affecting transcriptional and posttranscriptional levels. ${ }^{118-120}$ Currently, for both cell behavior and clinicopathological factors, significant advances with respect to lncRNA effects on GC have been discovered. ${ }^{121}$

On account of the obvious expression differences between normal and malignant tissues as well as causal roles of lncRNAs in cancer development, lncRNAs are now attracting increasing attention, which has led to numerous investigations of the correlation between lncRNA states and clinical results in GC. Nevertheless, most of these studies were performed with small samples, and there were inconsistently observed connections. Consequently, we conducted a meta-analysis to determine the accurate role of lncRNAs in the prognosis of GC patients, which possibly supplied us with new insights into the clinical value of combined detection in forecasting prognostic results and determining promising biomarkers in GC treatment strategies.

\section{Methods}

\section{Literature search strategy}

We basically performed a systematic selection of papers published in English from four databases (PubMed, Web of Science, Embase and Cochrane Database of Systematic Reviews). A comprehensive search was conducted using the subject term: IncRNA and gastric cancer. Two authors (Song Gao and Zhi-Ying Zhao) checked the titles and abstracts of the retrieved papers, and Yue Zhang reevaluated uncertain data. Figure 1 shows the flow diagram of the literature search and selection.

\section{Inclusion criteria}

We set up inclusion criteria for qualified papers, which were analyzed using our full-text assessment: 1) articles

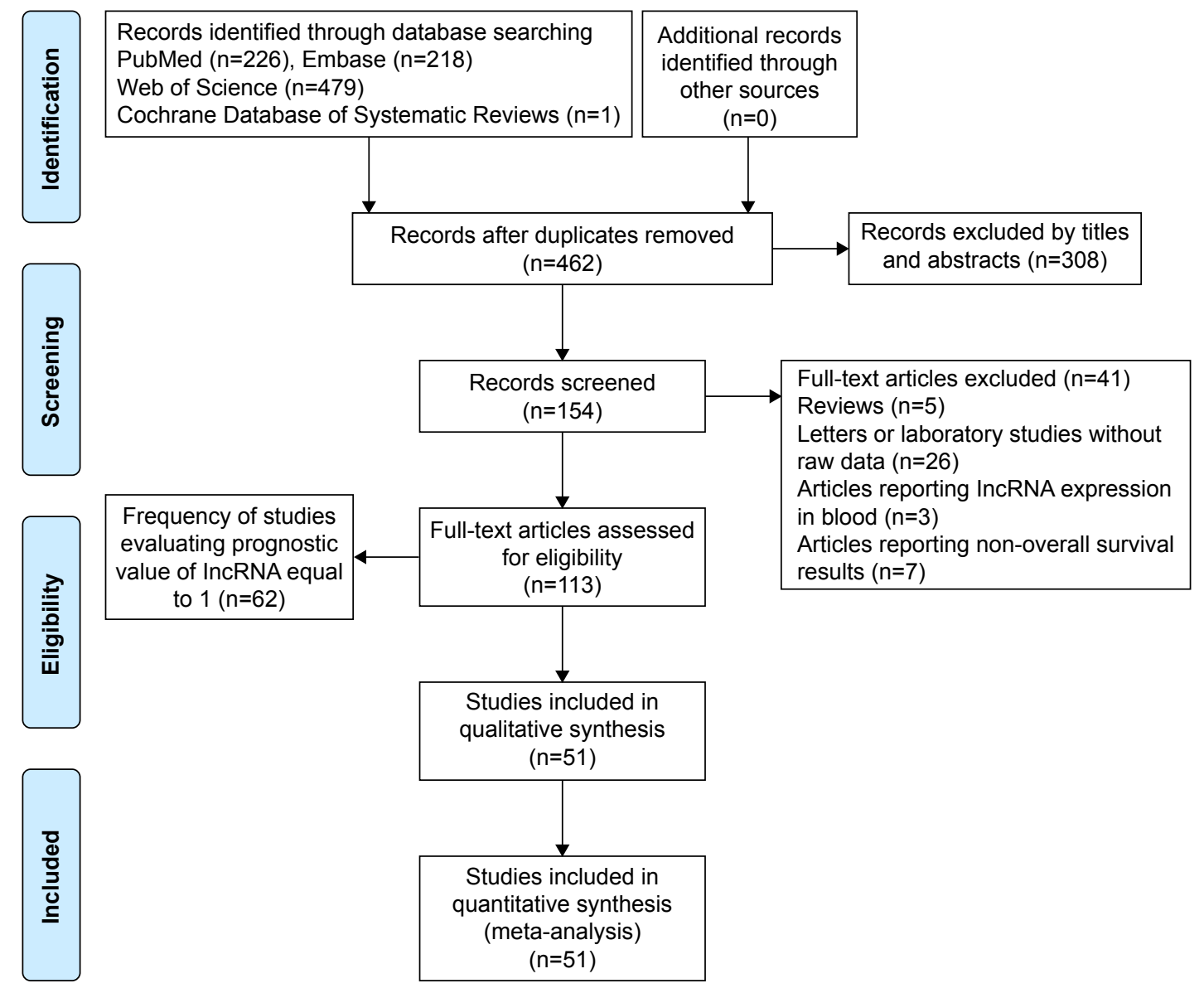

Figure I Flow diagram of the literature search and selection. Abbreviation: IncRNA, long noncoding RNA. 
concerning the pertinence between lncRNA level in cancer tissues and prognosis of GC patients; 2) the survival results were estimated using overall survival (OS) and 3) full-text papers published in English.

\section{Exclusion criteria}

Articles that did not meet the abovementioned inclusion criteria, reviews, letters and laboratory studies without raw data were excluded. Articles of non-dichotomous lncRNA expression levels and frequency of studies evaluating prognostic value of IncRNAs equal to 1 were also excluded. If more than one paper had been published on the identical study cohort, only the most well-rounded investigation was selected for this research. In addition, if both of the univariate and multivariate outcomes were covered, only the latter were chosen, since they were adjusted for confounding factors.

\section{Research frequency}

Table 1 gives the frequency of investigations reporting prognosis of GC patients, which included the lncRNA name, frequency of researched lncRNA and reference.

\section{Data extraction}

The survival data were recovered from qualified articles independently by two authors (Song Gao and Zhi-Ying Zhao). Data extracted from them are as follows: researched lncRNA,

Table I Research frequency of IncRNAs in GC

\begin{tabular}{|c|c|c|c|c|c|c|c|c|}
\hline IncRNA & $\mathbf{n}$ & $\mathbf{R}$ & IncRNA & $\mathbf{n}$ & $\mathbf{R}$ & IncRNA & $\mathbf{n}$ & $\mathbf{R}$ \\
\hline AC027II9.I & $\mathrm{I}$ & $\mathrm{I}$ & $\mathrm{HI9}$ & 4 & $29,36-38$ & NEATI & $\mathrm{I}$ & 83 \\
\hline $\mathrm{ACI} 38 \mathrm{I} 28 . \mathrm{I}$ & $\mathrm{I}$ & 2 & HAGLROS & $\mathrm{I}$ & 39 & NR_003573 & $\mathrm{I}$ & 7 \\
\hline ADAMTS9-AS2 & $I$ & I & HIFIA-AS2 & $I$ & 40 & OR3A4 & $\mathrm{I}$ & 84 \\
\hline AFAPI-ASI & 2 & 3,4 & HOTAIR & 9 & $41-59$ & OTUBI-isoform 2 & $\mathrm{I}$ & 85 \\
\hline AGAP2-ASI & $\mathrm{I}$ & 5 & HOTTIP & 3 & $50-52$ & PANDAR & 2 & 86,87 \\
\hline AK02339I & $\mathrm{I}$ & 6 & HOXA-AS2 & $\mathrm{I}$ & 53 & PCATI & $\mathrm{I}$ & 88 \\
\hline AK093735 & I & 7 & HXAII-AS & I & 54 & PVTI & 2 & 89,90 \\
\hline AKI 23072 & I & 8 & KRTI8P55 & I & 55 & RPII-II9F7.4 & I & 91 \\
\hline ANRIL & 2 & 9,10 & LET & $\mathrm{I}$ & 56 & RPII-I20KI8.2 & I & 1 \\
\hline ATB & $\mathrm{I}$ & 11 & LINC00052 & $\mathrm{I}$ & 57 & RPII-389G6.3 & $\mathrm{I}$ & 1 \\
\hline BANCR & I & 12 & LINC00I52 & I & 58 & RPII-499F3.2 & I & I \\
\hline BC005927 & $\mathrm{I}$ & 13 & LINC00628 & $\mathrm{I}$ & 59 & RPII-789CI.I & $\mathrm{I}$ & 92 \\
\hline BC032469 & $\mathrm{I}$ & 14 & LINC00668 & $\mathrm{I}$ & 60 & RPLPOP2 & I & 29 \\
\hline $\mathrm{BC} 04195 \mathrm{I}$ & $\mathrm{I}$ & 15 & LINC00673 & 2 & 61,62 & SLC26A4 & $\mathrm{I}$ & 29 \\
\hline BCAR4 & $\mathrm{I}$ & 16 & LINC00675 & $\mathrm{I}$ & 63 & SMIMIOL2A & $\mathrm{I}$ & 29 \\
\hline CASC2 & $\mathrm{I}$ & 17 & LINC00982 & $\mathrm{I}$ & 64 & SMIMIOL2B & $\mathrm{I}$ & 29 \\
\hline CASCI5 & 2 & 18,19 & LINC0I0I8 & $\mathrm{I}$ & 65 & SNHGI & $\mathrm{I}$ & 93 \\
\hline CCATI & $\mathrm{I}$ & 20 & LINC0I 234 & $\mathrm{I}$ & 66 & SNHG6 & $\mathrm{I}$ & 94 \\
\hline CCAT2 & 2 & 21,22 & LINC0I 296 & $\mathrm{I}$ & 67 & SNHGI 2 & $I$ & 95 \\
\hline CHRDLI & 1 & 23 & LINC-ROR & $\mathrm{I}$ & 68 & SNORDII6-4 & I & 29 \\
\hline CTD-2I47F2.I & $\mathrm{I}$ & $\mathrm{I}$ & LINC-UBCI & $\mathrm{I}$ & 69 & Sox2ot & 2 & 96,97 \\
\hline DANCR & I & 24 & LOCI00I30476 & $\mathrm{I}$ & 70 & SPRY4-ITI & 2 & 98,99 \\
\hline DLX6-ASI & $\mathrm{I}$ & $\mathrm{I}$ & LOC553I37 & $\mathrm{I}$ & 65 & TINCR & $\mathrm{I}$ & 29 \\
\hline E2FI & $\mathrm{I}$ & 25 & $\mathrm{MACCI}$ & $\mathrm{I}$ & 71 & TTTYI4 & $\mathrm{I}$ & 65 \\
\hline EGOT & $\mathrm{I}$ & 26 & MACCI-ASI & $\mathrm{I}$ & 71 & TUGI & $\mathrm{I}$ & 100 \\
\hline FENDRR & $\mathrm{I}$ & 27 & MALATI & 4 & $43,72-74$ & UCAI & 4 & $101-104$ \\
\hline FEZFI-ASI & $\mathrm{I}$ & 28 & MANCR & $\mathrm{I}$ & 75 & VPS9DI-ASI & $\mathrm{I}$ & 105 \\
\hline FOXD2-ASI & $\mathrm{I}$ & 29 & MEG3 & 2 & 76,77 & XIAP-ASI & $\mathrm{I}$ & 106 \\
\hline FRLncl & $\mathrm{I}$ & 30 & MIR3IHG & $\mathrm{I}$ & 78 & XIST & 2 & 107,108 \\
\hline GACAT3 & $\mathrm{I}$ & 31 & MIR4435-2HG & $\mathrm{I}$ & 65 & XLOC_0I0235 & $\mathrm{I}$ & 92 \\
\hline GAPLINC & 2 & 32,33 & MLK7-ASI & $\mathrm{I}$ & 79 & ZEBI-ASI & 2 & 109,110 \\
\hline GAS5 & 1 & 34 & MLLT4-ASI & $I$ & 80 & ZFASI & 2 & 111,112 \\
\hline GBETI & $\mathrm{I}$ & 35 & MRUL & $\mathrm{I}$ & 81 & ZMATI & $\mathrm{I}$ & 113 \\
\hline GClncl & $I$ & 15 & MTM & 1 & 82 & & & \\
\hline
\end{tabular}

Notes: Highlighted IncRNAs were included in the meta-analysis. n, number of research frequency; R, reference.

Abbreviations: AFAPI-ASI, AFAPI antisense RNA I; ANRIL, CDKN2B antisense RNA I; CASCI5, cancer susceptibility 15; CCAT2, colon cancer associated transcript 2; GAPLINC, gastric adenocarcinoma associated, positive CD44 regulator, long intergenic noncoding RNA; GC, gastric cancer; HI9, HI9, imprinted maternally expressed transcript; HOTAIR, HOX transcript antisense RNA; HOTTIP, HOXA distal transcript antisense RNA; LINC00673, long intergenic non-protein coding RNA 673; IncRNA, long noncoding RNA; MALATI, metastasis-associated lung adenocarcinoma transcript I; MEG3, maternally expressed 3; PANDAR, promoter of CDKNIA antisense DNA damage activated RNA; PVTI, PvtI oncogene; Sox2ot, SOX2 overlapping transcript; SPRY4-ITI, SPRY4 intronic transcript I; UCAI, urothelial cancer associated I; XIST, $X$ inactive specific transcript; ZEBI-ASI, ZEBI antisense RNA I; ZFASI, ZNFXI antisense RNA I. 
first author's name, paper publication year, reference, patient's nationality, study design, histological type, patient number, neoplasm staging, cutoff value, detected method, follow-up period, survival analysis type, HRs and 95\% CIs. The detailed data are shown in Table 2. If HR and 95\% CI were not directly shown in the paper, data from survival curve were extracted. Disagreements were discussed with the third investigator (Yue Zhang).

\section{Statistical analysis}

Stata version 13.0 (StataCorp LP, College Station, TX, USA) was used for the whole meta-analysis. HR and 95\% CI from GC patients were calculated on the basis of survival curve and patient number using Engauge Digitizer version 4.1 and Tierney's method. ${ }^{122}$ The random-effect model was used in the whole article because different histological type (frozen, formalin-fixed paraffin-embedded or undefined) from GC patients at different neoplasm staging, cutoff value and lncRNA detected method was used in the single study. The HR was considered significant if its $P$-value was $<0.05$ and $95 \%$ CI did not contain the value 1 . Furthermore, the lncRNA was considered as a strong biomarker of prognosis, if its HR was $>2$. The Begg's funnel plot was used to estimate publication bias, and a two-tailed $P$-value $<0.05$ was considered as significant. The sensitivity analysis was performed to examine how sensitive the merged HR was if the single study was removed, and if the point of evaluation was outside the 95\% CI after it was removed from the whole analysis, a single research was considered as excessive influence.

\section{Results}

\section{Meta-analysis}

Table 3 gives the basic information of the merged metaanalysis for researched lncRNAs.

AFAPI antisense RNA I (AFAPI-ASI), CDKN2B antisense RNA I (ANRIL), cancer susceptibility I5 (CASCI5), colon cancer-associated transcript 2 (CCAT2), gastric adenocarcinoma associated, positive CD44 regulator, long intergenic noncoding RNA (GAPLINC) and HI9, imprinted maternally expressed transcript (HI9) demonstrated significantly prognostic value

Two articles ${ }^{3,4}$ reported the relationship between high AFAP1AS1 expression and OS, indicating that GC patients with its high expression had significantly worse OS than those with its low expression $(\mathrm{HR}=2.47,95 \% \mathrm{CI}=1.41-4.30, P<0.01)$.

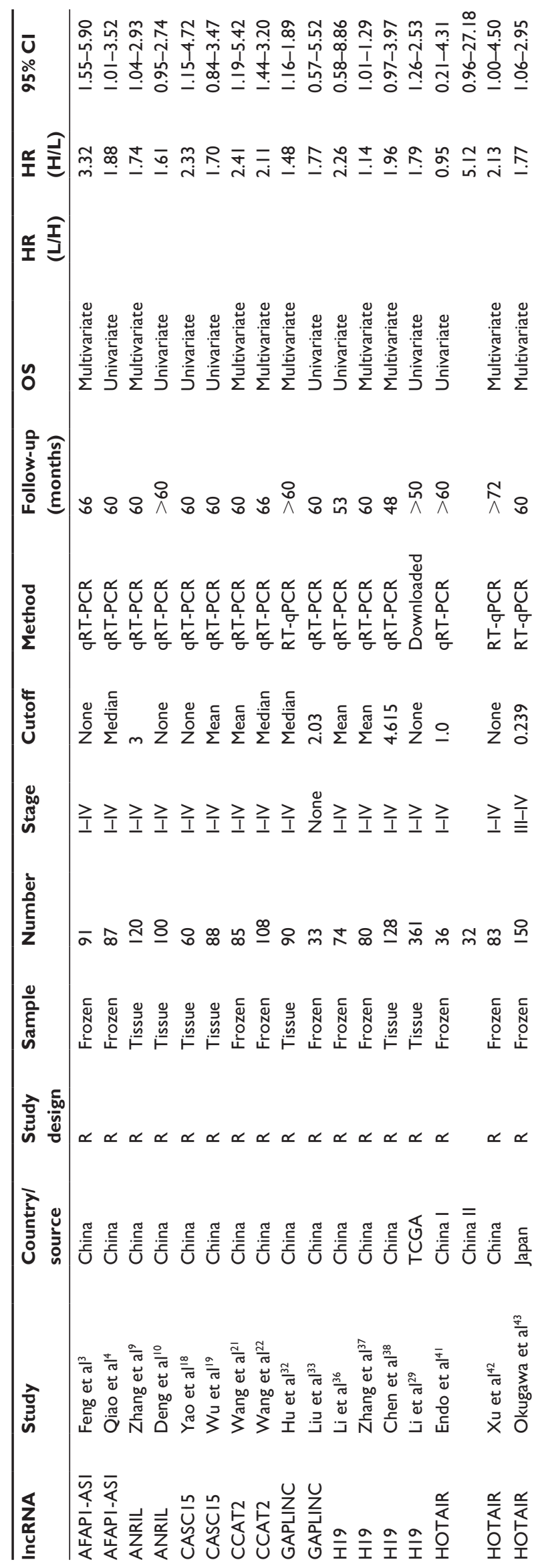


to

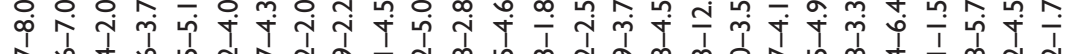

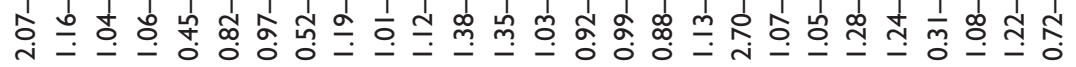

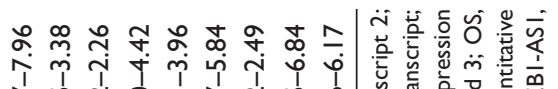

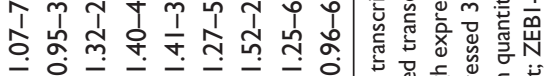

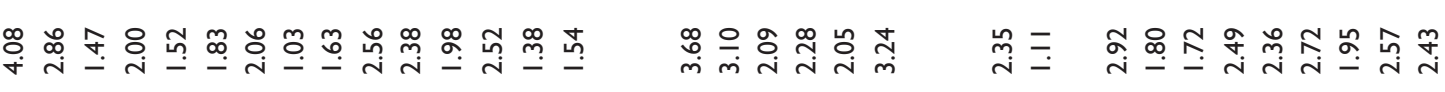

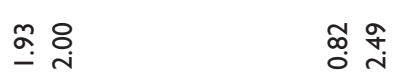

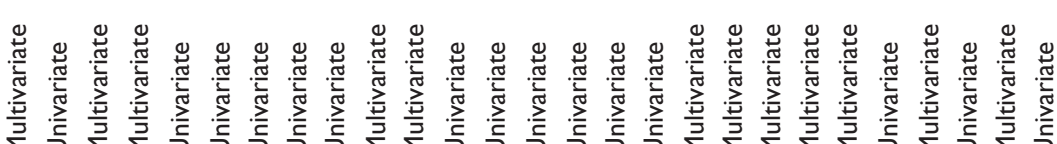

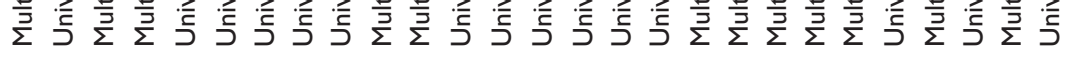

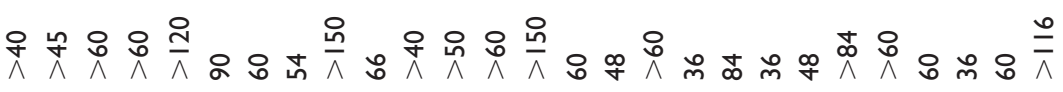

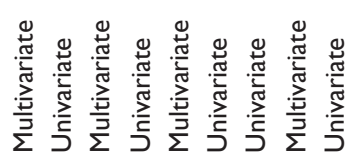

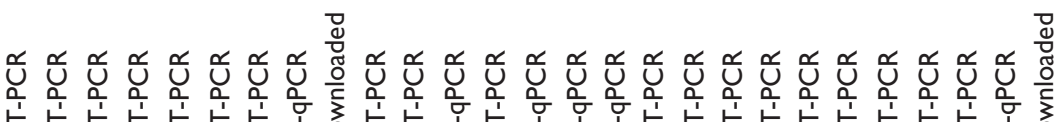

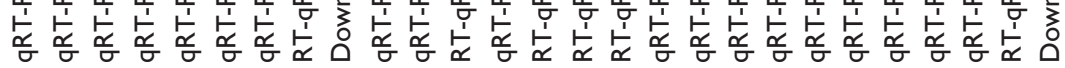

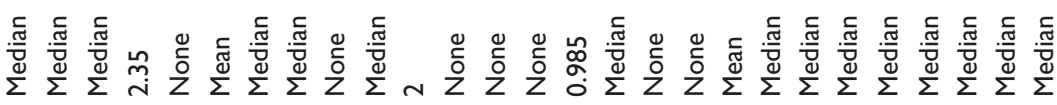

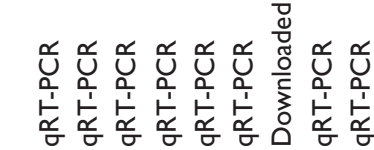

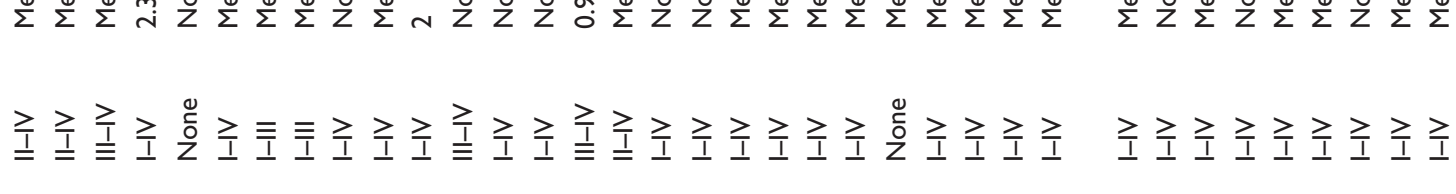

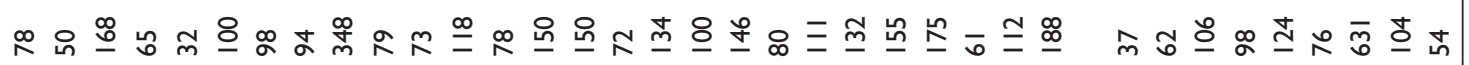

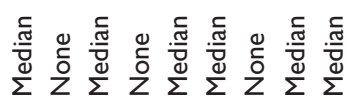

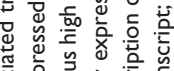

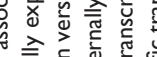

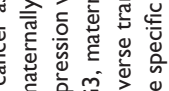
으의

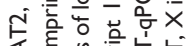

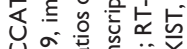

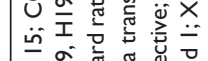

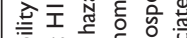
穿

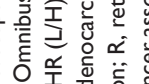

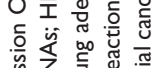

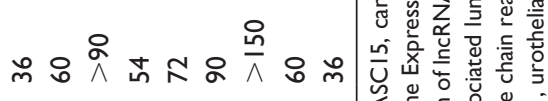

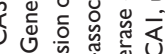

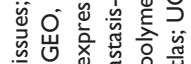

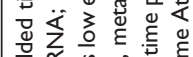

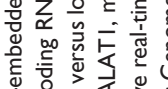

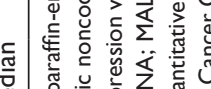

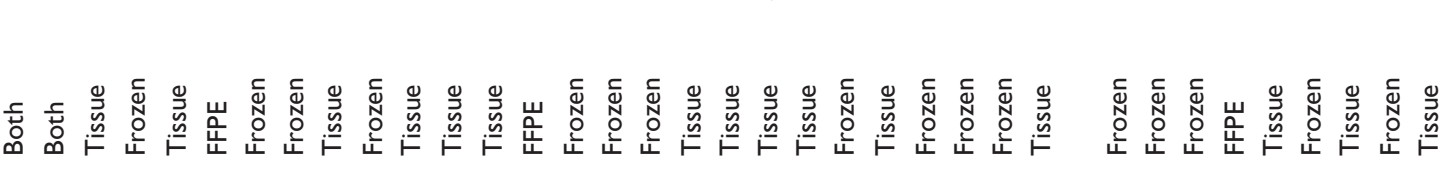

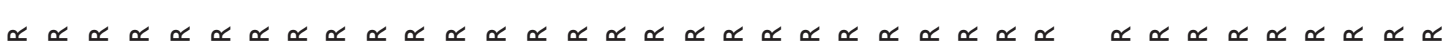

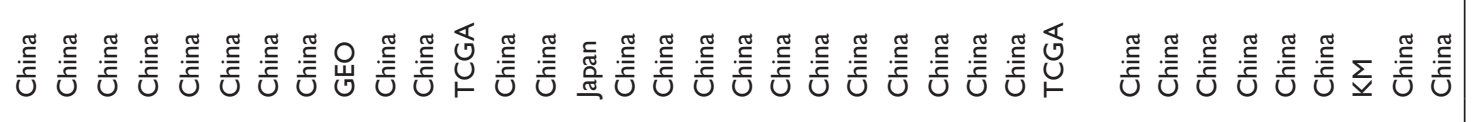

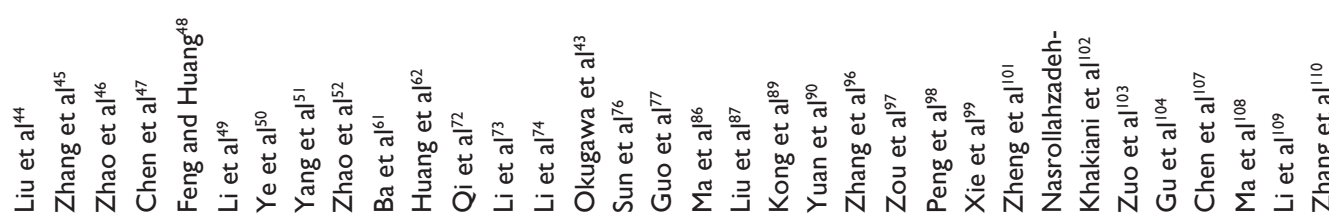

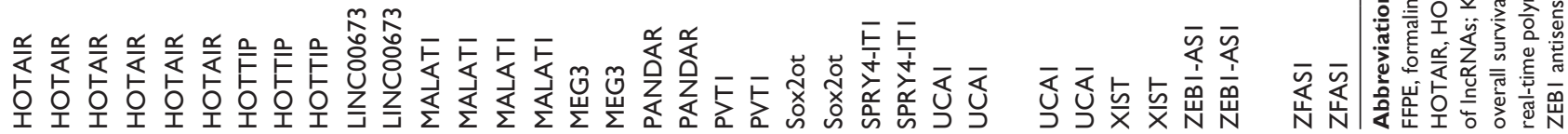


Table $3 \mathrm{HR}$ with $95 \% \mathrm{Cl}$ of IncRNA expression in GC

\begin{tabular}{|c|c|c|c|c|c|c|c|c|}
\hline IncRNA & $\begin{array}{l}\text { Number } \\
\text { of articles }\end{array}$ & $\begin{array}{l}\text { Included } \\
\text { articles }\end{array}$ & HR & $95 \% \mathrm{Cl}$ & Figure & $P$-value & $\begin{array}{l}\text { Heterogeneity } \\
\text { (Higgins I' } \text { statistic) }\end{array}$ & $\begin{array}{l}\text { Total } \\
\text { patients }\end{array}$ \\
\hline High AFAPI-ASI & 2 & 3,4 & 2.47 & $|.4|-4.30$ & 2 & $<0.01$ & $P^{2}=32.7 \%, P=0.22$ & 178 \\
\hline High ANRIL & 2 & 9,10 & 1.68 & $1.16-2.43$ & 2 & $<0.01$ & $P^{2}=0.0 \%, P=0.84$ & 220 \\
\hline High CASCI5 & 2 & 18,19 & 1.99 & $1.21-3.28$ & 2 & $<0.01$ & $P^{2}=0.0 \%, P=0.54$ & 148 \\
\hline High CCAT2 & 2 & 21,22 & 2.17 & $1.53-3.09$ & 2 & $<0.01$ & $P^{2}=0.0 \%, P=0.76$ & 193 \\
\hline High GAPLINC & 2 & 32,33 & 1.49 & $1.18-1.89$ & 2 & $<0.01$ & $P^{2}=0.0 \%, P=0.76$ & 123 \\
\hline High HI9 & 4 & $29,36-38$ & 1.51 & $1.05-2.17$ & 2 & 0.03 & $P^{2}=64.1 \%, P=0.04$ & 643 \\
\hline High HOTAIR & 9 & $41-49$ & 1.93 & I.53-2.43 & 3 & $<0.01$ & $P^{2}=|4.0 \%, P=0.3|$ & 794 \\
\hline High HOTTIP & 3 & $50-52$ & 1.57 & $1.20-2.05$ & 6 & $<0.01$ & $P^{2}=0.2 \%, P=0.37$ & 540 \\
\hline High LINC00673 & 2 & 61,62 & 2.47 & $1.45-4.20$ & 6 & $<0.01$ & $P^{2}=0.0 \%, P=0.89$ & 152 \\
\hline High MALATI & 4 & $43,72-74$ & 1.70 & $1.33-2.18$ & 6 & $<0.01$ & $P^{2}=29.7 \%, P=0.23$ & 496 \\
\hline Low MEG3 & 2 & 76,77 & 1.96 & I.17-3.28 & 6 & 0.01 & $P^{2}=0.0 \%, P=0.95$ & 206 \\
\hline High PANDAR & 2 & 86,87 & 3.11 & $2.72-3.55$ & 6 & $<0.01$ & $P^{2}=0.0 \%, P=0.79$ & 246 \\
\hline High PVTI & 2 & 89,90 & 2.17 & $1.31-3.60$ & 6 & $<0.01$ & $P^{2}=0.0 \%, P=0.87$ & 191 \\
\hline High Sox2ot & 2 & 96,97 & 2.30 & $1.52-3.46$ & 7 & $<0.01$ & $P^{2}=0.0 \%, P=0.35$ & 287 \\
\hline Low SPRY4-ITI & 2 & 98,99 & 1.42 & $0.48-4.22$ & 7 & 0.53 & $P^{2}=71.4 \%, P=0.06$ & 236 \\
\hline High UCAI & 4 & $101-104$ & 1.73 & I.12-2.68 & 7 & 0.01 & $P^{2}=45.5 \%, P=0.14$ & 399 \\
\hline High XIST & 2 & 107,108 & 1.89 & $1.38-2.59$ & 7 & $<0.01$ & $P^{2}=23.4 \%, P=0.25$ & 204 \\
\hline High ZEBI-ASI & 2 & 109,110 & 2.07 & $1.67-2.56$ & 7 & $<0.01$ & $P^{2}=0.0 \%, P=0.62$ & 831 \\
\hline High ZFASI & 2 & 111,112 & 2.51 & $1.34-4.69$ & 7 & $<0.01$ & $P^{2}=0.0 \%, P=0.93$ & 158 \\
\hline
\end{tabular}

Abbreviations: AFAPI-ASI, AFAPI antisense RNA I; ANRIL, CDKN2B antisense RNA I; CASCI5, cancer susceptibility I5; CCAT2, colon cancer associated transcript 2; GAPLINC, gastric adenocarcinoma associated, positive CD44 regulator, long intergenic noncoding RNA; GC, gastric cancer; HI9, HI9, imprinted maternally expressed transcript; HOTAIR, HOX transcript antisense RNA; HOTTIP, HOXA distal transcript antisense RNA; LINC00673, long intergenic non-protein coding RNA 673; IncRNA, long noncoding RNA; MALATI, metastasis-associated lung adenocarcinoma transcript I; MEG3, maternally expressed 3; PANDAR, promoter of CDKNIA antisense DNA damage activated RNA; PVTI, Pvt I oncogene; Sox2ot, SOX2 overlapping transcript; SPRY4-ITI, SPRY4 intronic transcript I; UCAI, urothelial cancer associated I; XIST, $X$ inactive specific transcript; ZEBI-ASI, ZEBI antisense RNA I; ZFASI, ZNFXI antisense RNA I.

Two researches ${ }^{9,10}$ covered the connections between high ANRIL expression and OS, suggesting that GC patients with its high expression had significantly poorer OS than those with its low expression $(\mathrm{HR}=1.68,95 \% \mathrm{CI}=1.16-2.43$, $P<0.01)$.

Two investigations ${ }^{18,19}$ analyzed the associations between high CASC15 expression and OS, showing that GC patients with its high expression had significantly shorter OS than those with its low expression ( $\mathrm{HR}=1.99,95 \% \mathrm{CI}=1.21-3.28$, $P<0.01)$.

Two studies ${ }^{21,22}$ focused on the correlation between high CCAT2 expression and OS, manifesting that GC patients with its high expression had significantly worse OS than those with its low expression $(\mathrm{HR}=2.17,95 \% \mathrm{CI}=1.53-3.09$, $P<0.01)$.

Two papers ${ }^{32,33}$ paid attention to the pertinence between high GAPLINC expression and OS, demonstrating that GC patients with its high expression had significantly poorer OS than those with its low expression $(\mathrm{HR}=1.49$, 95\% CI=1.18-1.89, $P<0.01$ ).

Four literature ${ }^{29,36-38}$ described the relativity between high H19 expression and OS, proving that GC patients with its high expression had significantly shorter OS than those with its low expression $(\mathrm{HR}=1.51,95 \% \mathrm{CI}=1.05-2.17, P=0.03$; Figure 2).

\section{HOX transcript antisense RNA (HOTAIR)} demonstrated significantly prognostic value Nine essays ${ }^{41-49}$ discussed the relation between high HOTAIR expression and OS, illuminating that GC patients with its high expression had significantly worse OS than those with its low expression $(\mathrm{HR}=1.93,95 \% \mathrm{CI}=1.53-2.43, P<0.01$; Figure 3).

\section{Publication bias}

The Begg's funnel plot was used to estimate publication bias, and its $P$-value was 0.20 , so there was no significant publication bias in the pooled analysis of OS about high HOTAIR expression (Figure 4).

\section{Sensitivity analysis}

The sensitivity analysis was performed to examine how sensitive the merged HR was if the single study was removed. 


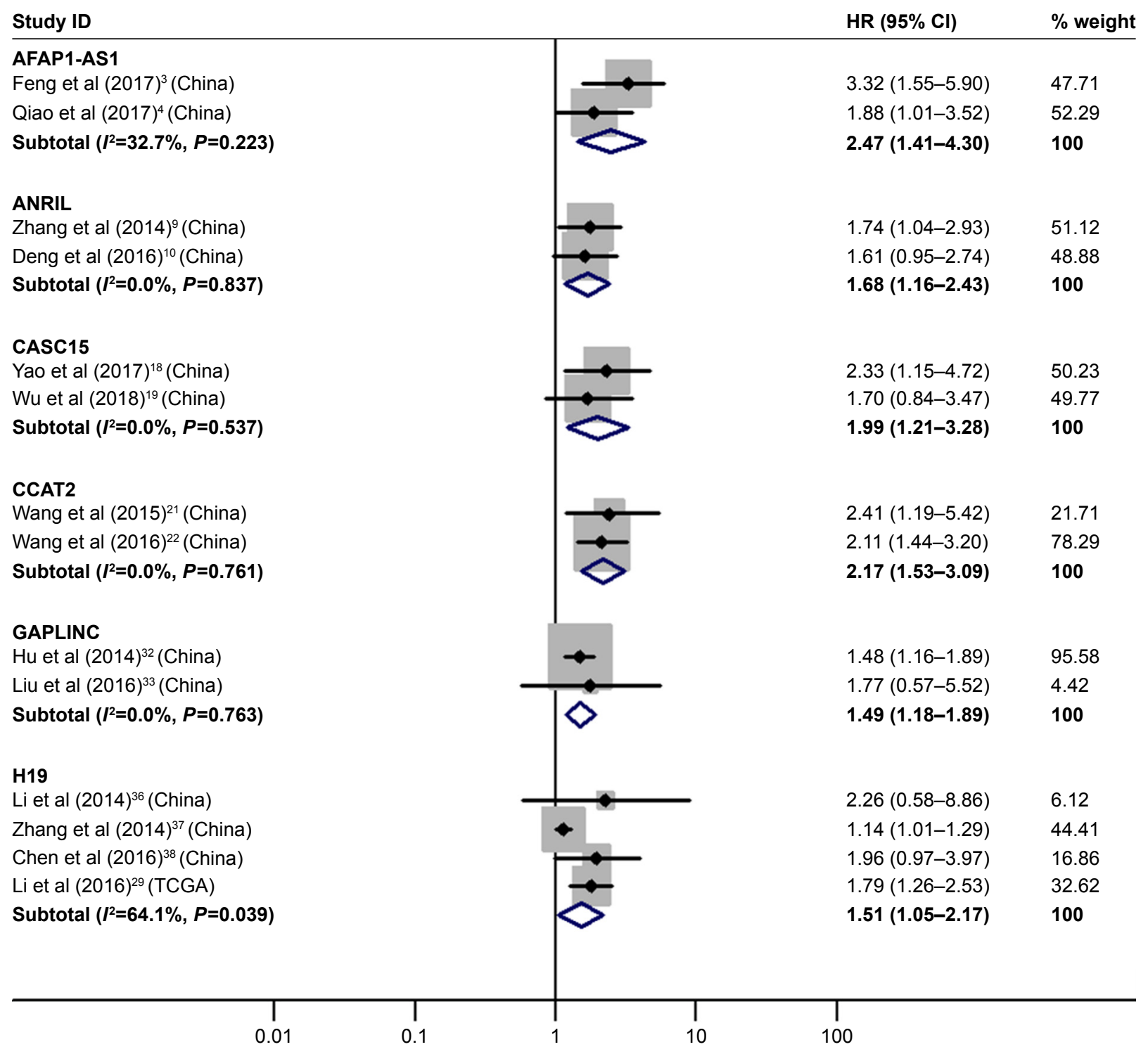

Figure 2 Forest plot of pooled analyses of OS in association with high AFAPI-ASI, ANRIL, CASCI5, CCAT2, GAPLINC and HI 9 expression levels. Note: Weights are from random-effects analysis.

Abbreviations: AFAPI-ASI, AFAPI antisense RNA I; ANRIL, CDKN2B antisense RNA I; CASCI5, cancer susceptibility 15; CCAT2, colon cancer associated transcript 2; GAPLINC, gastric adenocarcinoma associated, positive CD44 regulator, long intergenic noncoding RNA; HI9, HI9, imprinted maternally expressed transcript. OS, overall survival.

After this process, no individual study significantly affected the combined HR with 95\% CI (Figure 5).

HOXA distal transcript antisense RNA (HOTTIP), long intergenic non-protein coding RNA 673 (LINC00673), metastasis-associated lung adenocarcinoma transcript I (MALATI), maternally expressed 3 (MEG3), promoter of CDKNIA antisense DNA damage activated RNA (PANDAR) and Pvtl oncogene (PVTI) demonstrated significantly prognostic value

The details are shown in Table 3 and Figure 6.
SOX2 overlapping transcript (Sox2ot), urothelial cancer-associated I (UCAI), X inactive specific transcript (XIST), ZEBI antisense RNA I (ZEBI-ASI) and ZNFXI antisense RNA I (ZFASI) demonstrated significantly prognostic value The details are shown in Table 3 and Figure 7.

\section{Discussion}

\section{Current situation}

So far, the clinical treatment of GC remains limited. In the past score years, there has been little progress in both traditional 


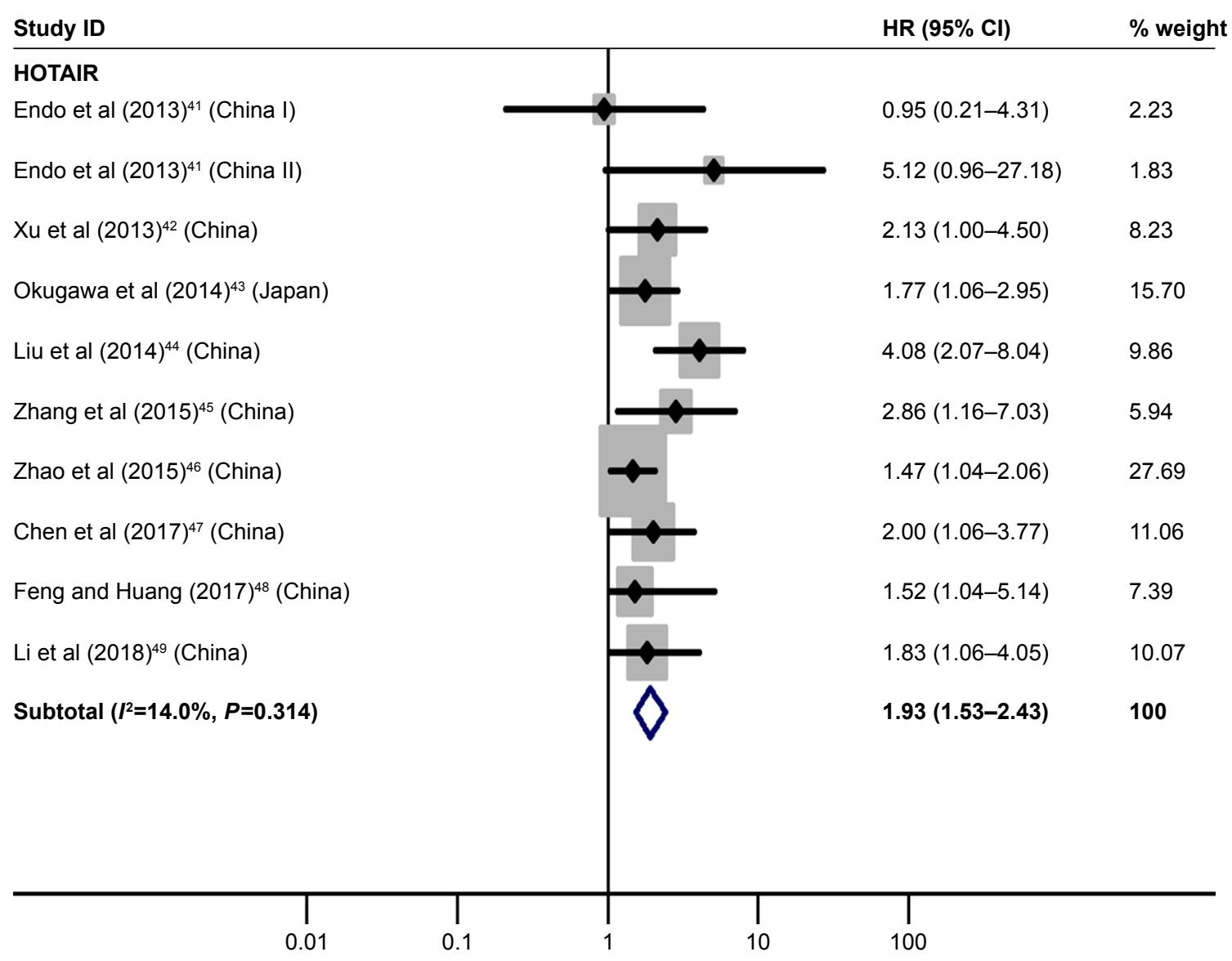

Figure 3 Forest plot of pooled analysis of OS in association with high HOTAIR expression levels.

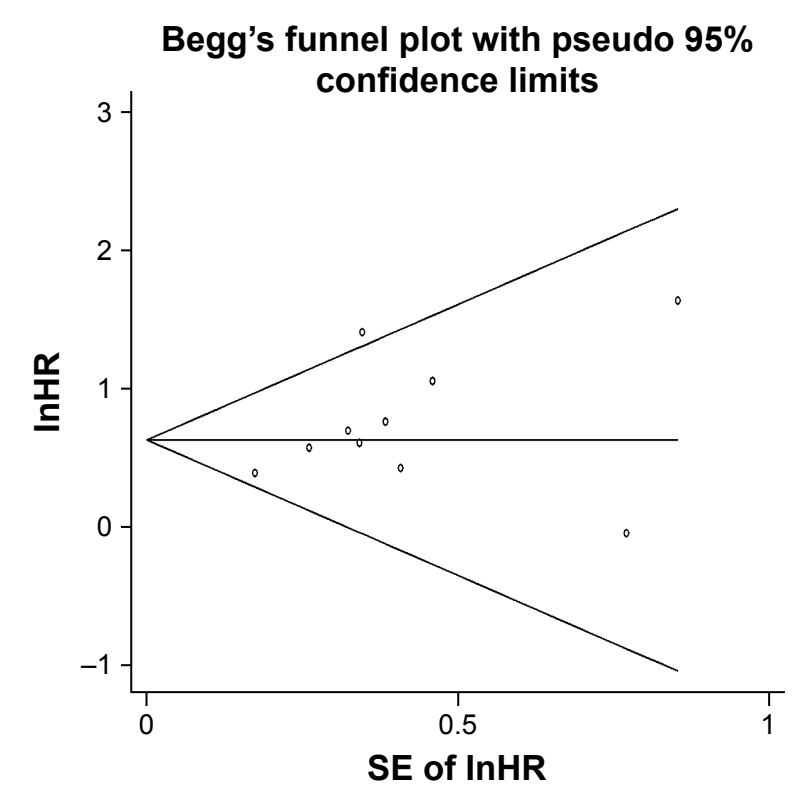

Figure 4 Beggs's funnel plot of publication bias for pooled analysis of OS in association with high HOTAIR expression levels.

Abbreviations: HOTAIR, HOX transcript antisense RNA; OS, overall survival; $\mathrm{SE}$, standard error. and new treatment methods. Therefore, novel biomarkers that can improve the prognosis of GC patients are in need. Recently, there is an increasing evidence that lncRNAs can hinder the growth and metastasis of cancer. For example, $\mathrm{Xu}$ et $\mathrm{al}^{123}$ reported that upregulating long stress-induced noncoding 5 (LSINCT5) significantly promoted the growth of the GC cell, while downregulating LSINCT5 suppressed its growth. Dan et $\mathrm{al}^{124}$ conducted the cancer model experiments using mice, proving that MEG3 overexpression could suppress GC growth and metastasis in vivo by suppressing miR-21 expression. More importantly, several abnormally expressed lncRNAs have been discovered to touch upon the development of GC and perhaps possess prognostic potency in this illness. In view of the above consequences, we conducted this metaanalysis about the prognostic value of lncRNAs in GC.

\section{Research finding}

In the present research, a total of 51 articles reporting 19 lncRNAs, which were latent prognostic biomarkers and 


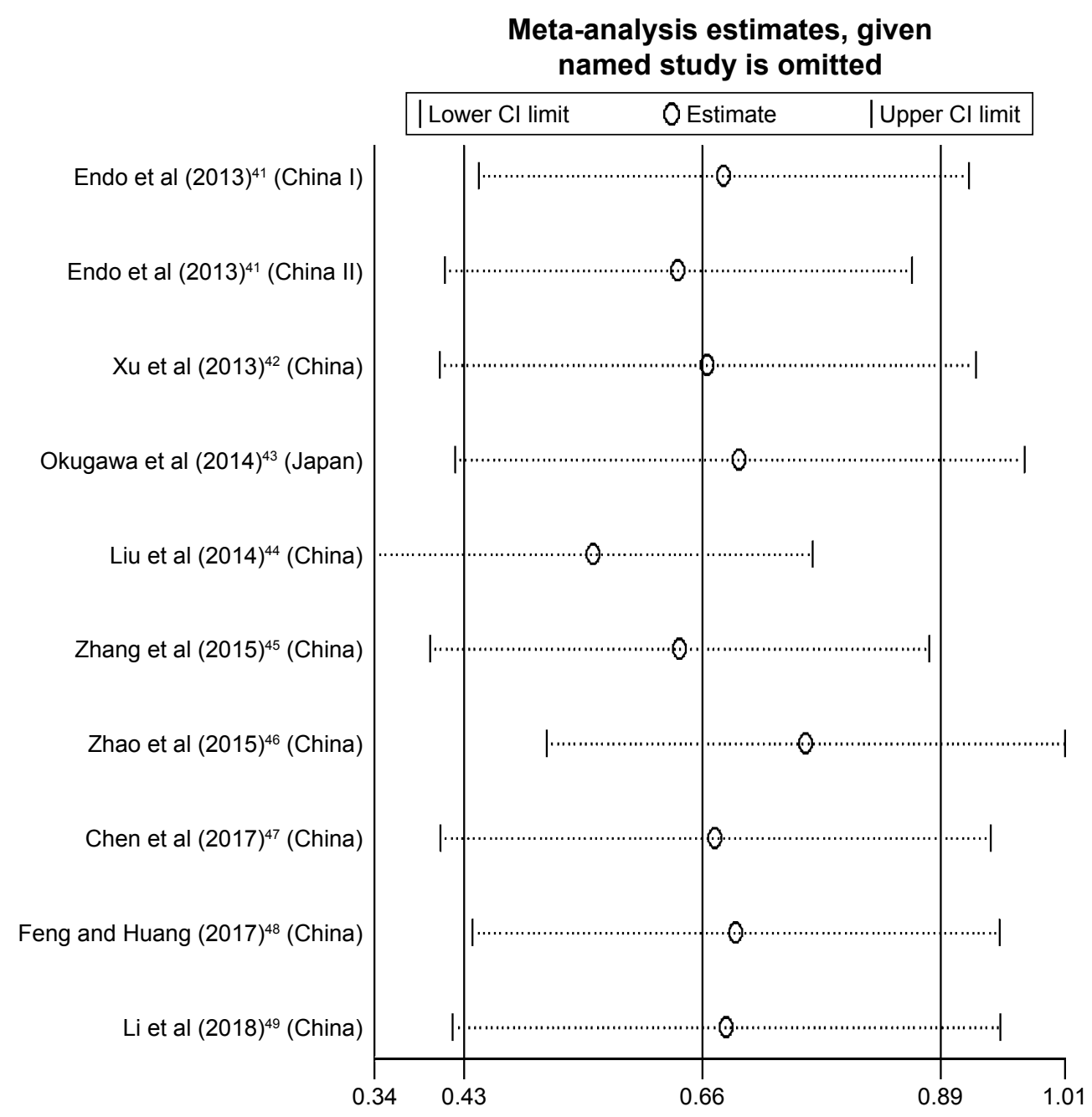

Figure 5 Sensitivity analysis of pooled analysis of OS in association with high HOTAIR expression levels. Abbreviations: HOTAIR, HOX transcript antisense RNA; OS, overall survival.

6,095 GC patients were included, among which 18 lncRNAs (except SPRY4 intronic transcript 1 [SPRY4-IT1]) manifested a significantly prognostic value. Meanwhile, strong heterogeneity was only shown in two (H19 and SPRY4-IT1) analyses about lncRNAs, during which there was no significant associations between SPRY4-IT1 expression and OS. Further analysis suggested that AFAP1-AS1, CCAT2, LINC00673, PANDAR, PVT1, Sox2ot, ZEB1-AS1 and ZFAS1 were strong candidates in predicting prognosis of GC patients.

\section{Molecular mechanisms}

Figure 8 shows the summary of lncRNAs with aberrant expression, potential targets and pathways included in this study. It is noteworthy that there existed inconsistent outcomes about expression of HOTTIP and SPRY4-IT1 compared with normal controls, so these two lncRNAs were not shown to be up or down expressed. Unexpected results were findings that CDKN1A was target of both CASC15 and PANDAR and KLF2 was target of both LINC00673 and ZFAS1. In addition, cell proliferation was the most related cell function of these lncRNAs.

\section{Merits}

The current study had several merits: 1) nearly all articles appraising the associations between OS of GC patients and IncRNA expression were searched and are clearly shown in Table 1; 2) most of our meta-analyses revealed no or low heterogeneity $\left(I^{2} \leq 50.0 \%\right)$, indicating relatively consistent results of the meta-analyses and 3 ) all the included studies had a relatively large sample size ( $\geq 30)$, decreasing the error of low sample size to some degree. 


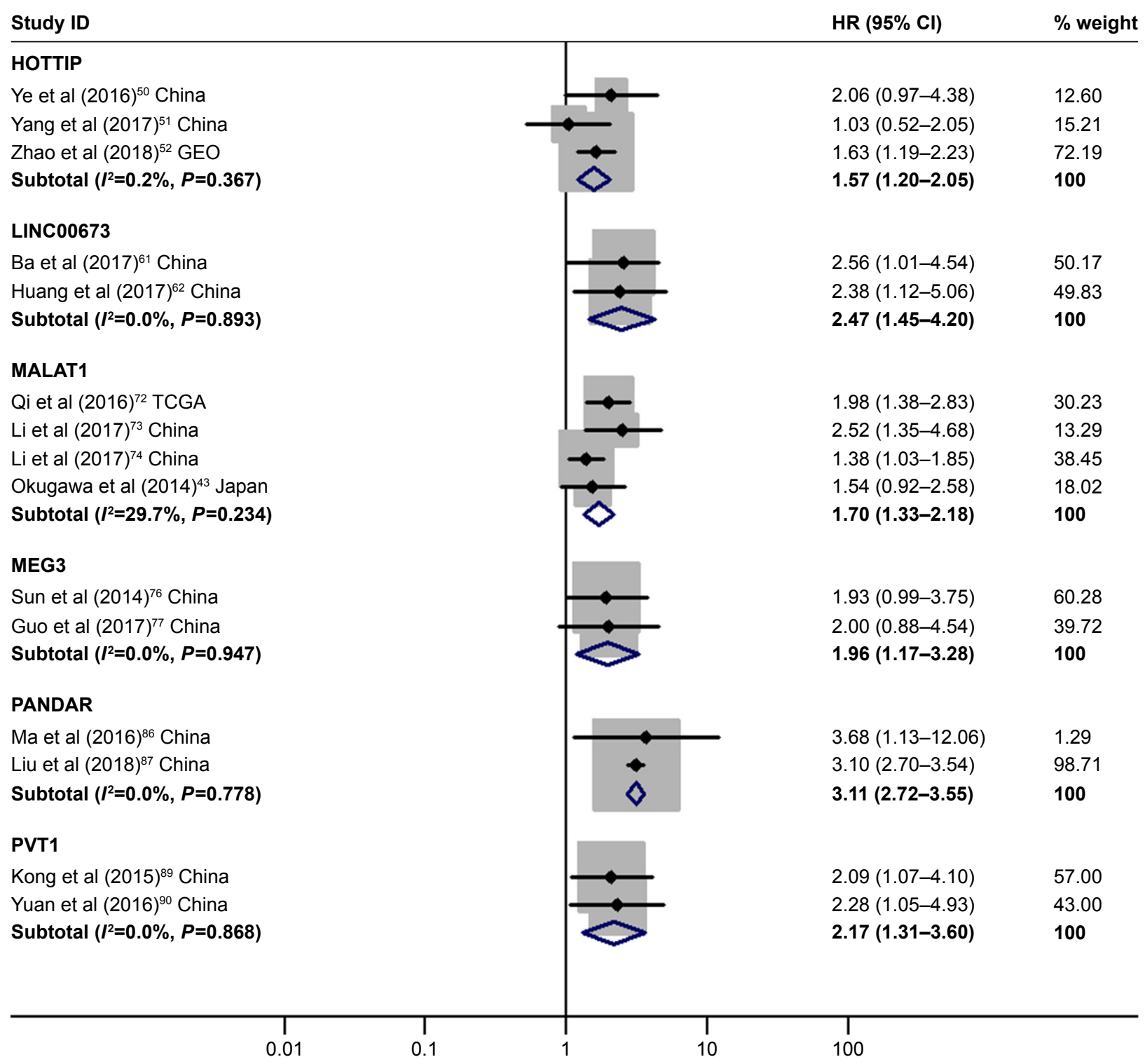

Figure 6 Forest plot of pooled analyses of OS in association with high HOTTIP, LINC00673, MALATI, PANDAR, PVTI expression levels, or low MEG3 expression levels. Note: Weights are from random-effects analysis.

Abbreviations: GEO, Gene Expression Omnibus; HOTTIP, HOXA distal transcript antisense RNA; LINC00673, long intergenic non-protein coding RNA 673; MALATI, metastasis-associated lung adenocarcinoma transcript I; MEG3, maternally expressed 3; OS, overall survival; PANDAR, promoter of CDKNIA antisense DNA damage activated RNA; PVTI, PvtI oncogene; TCGA, The Cancer Genome Atlas.

\section{Limitations}

However, the limitations of this work could not be ignored: 1) only English papers were included in the present research, which may exclude potentially relevant articles; 2) most of the patients were from China, which cannot adequately represent the prognosis of global patients; 3) only the metaanalysis of HOTAIR was composed of nine articles, ${ }^{41-49}$ and other merged analyses about lncRNAs were from relatively small article number (two to four) and 4) the papers omitted due to no mention of OS may provide a lot of information on which lncRNAs hold promise for a prognostic value.

\section{Inspirations}

This study left several inspirations for us: 1) lncRNAs were arranged in an alphabetical order as shown in Table 1, via which the recently research frequency could be distinctly seen by clinical workers and scientific researchers; 2) the detailed outcomes of OS from the pooled analyses are shown in Table 3, through which combined detection of lncRNAs might better predict the survival time of GC patients and 3 ) for the molecular mechanisms of the included lncRNAs, their connections are shown in Figure 8, which might play enlightening roles in future basic experiments on lncRNAs in GC. 


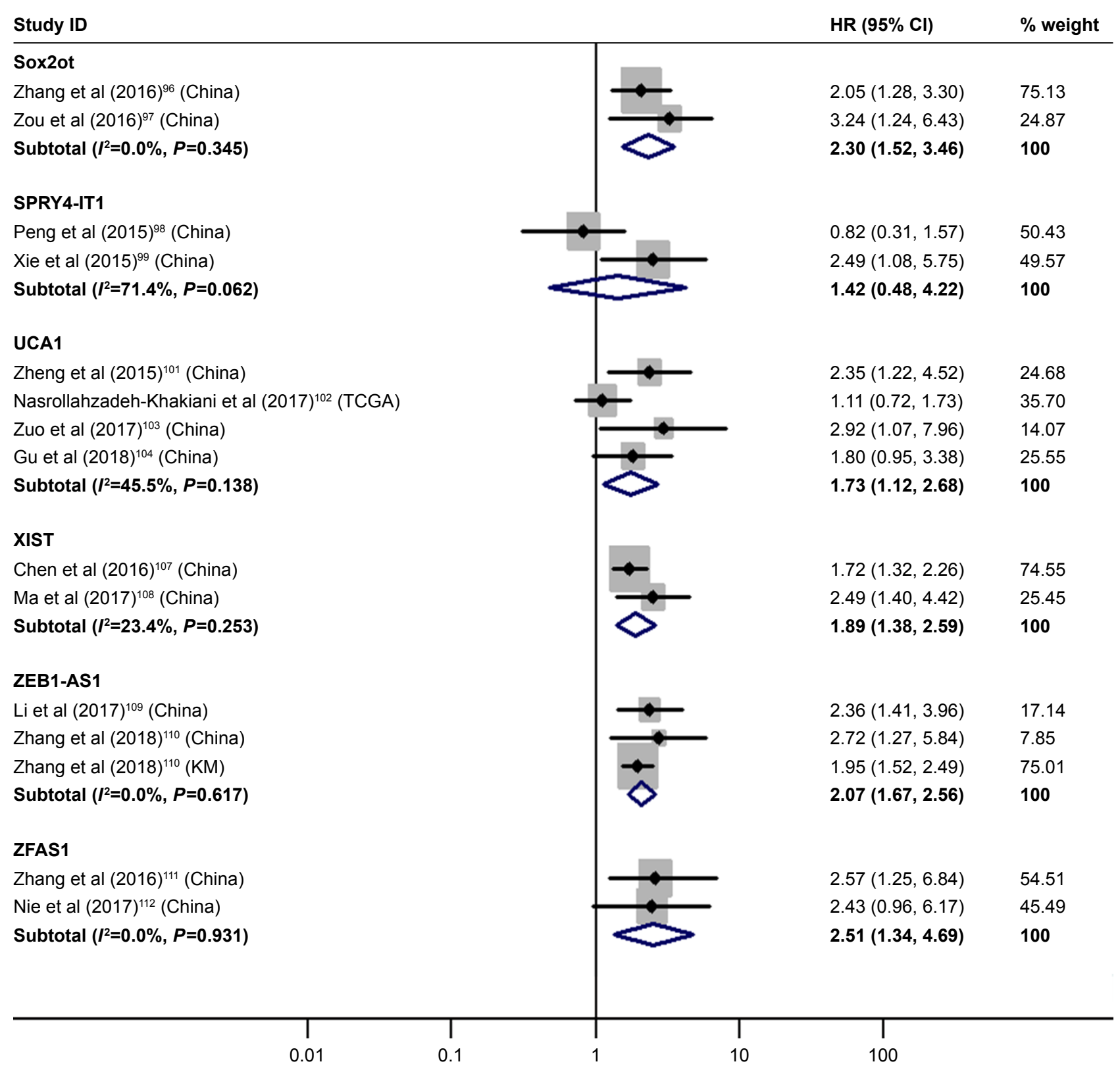

Figure 7 Forest plot of pooled analyses of OS in association with high Sox2ot, UCAI, XIST, ZEBI-ASI, ZFASI expression levels, or low SPRY4-ITI expression levels. Note: Weights are from random-effects analysis.

Abbreviations: OS, overall survival; Sox2ot, SOX2 overlapping transcript; SPRY4-ITI, SPRY4 intronic transcript I; UCAI, urothelial cancer associated I; XIST, X inactive specific transcript; ZEBI-ASI, ZEBI antisense RNA I; ZFASI, ZNFXI antisense RNA I.

\section{Conclusion}

This meta-analysis suggested that the abnormally expressed lncRNAs (AFAP1-AS1, ANRIL, CASC15, CCAT2, GAPLINC, H19, HOTAIR, HOTTIP, LINC00673, MALAT1, MEG3, PANDAR, PVT1, Sox2ot, UCA1, XIST, ZEB1-AS1 and ZFAS1) were significantly associated with the survival of GC patients, among which AFAP1-AS1, CCAT2, LINC00673, PANDAR, PVT1, Sox2ot, ZEB1-AS1 and ZFAS1 were strong candidates in predicting prognosis of GC patients.

\section{Author contributions}

Yue Zhang contributed toward study concept and design. Song Gao and Zhi-Ying Zhao were involved in acquisition of data. Song Gao, Zhi-Ying Zhao and Rong Wu carried out analysis and interpretation of data. Yue Zhang performed drafting of the manuscript. Song Gao, Zhi-Ying Zhao, Rong $\mathrm{Wu}$, Yue Zhang and Zhen-Yong Zhang assisted with revision of manuscript. Yue Zhang and Zhen-Yong Zhang helped in supervision of work. All authors read and approved the final manuscript. All authors contributed toward data analysis, 


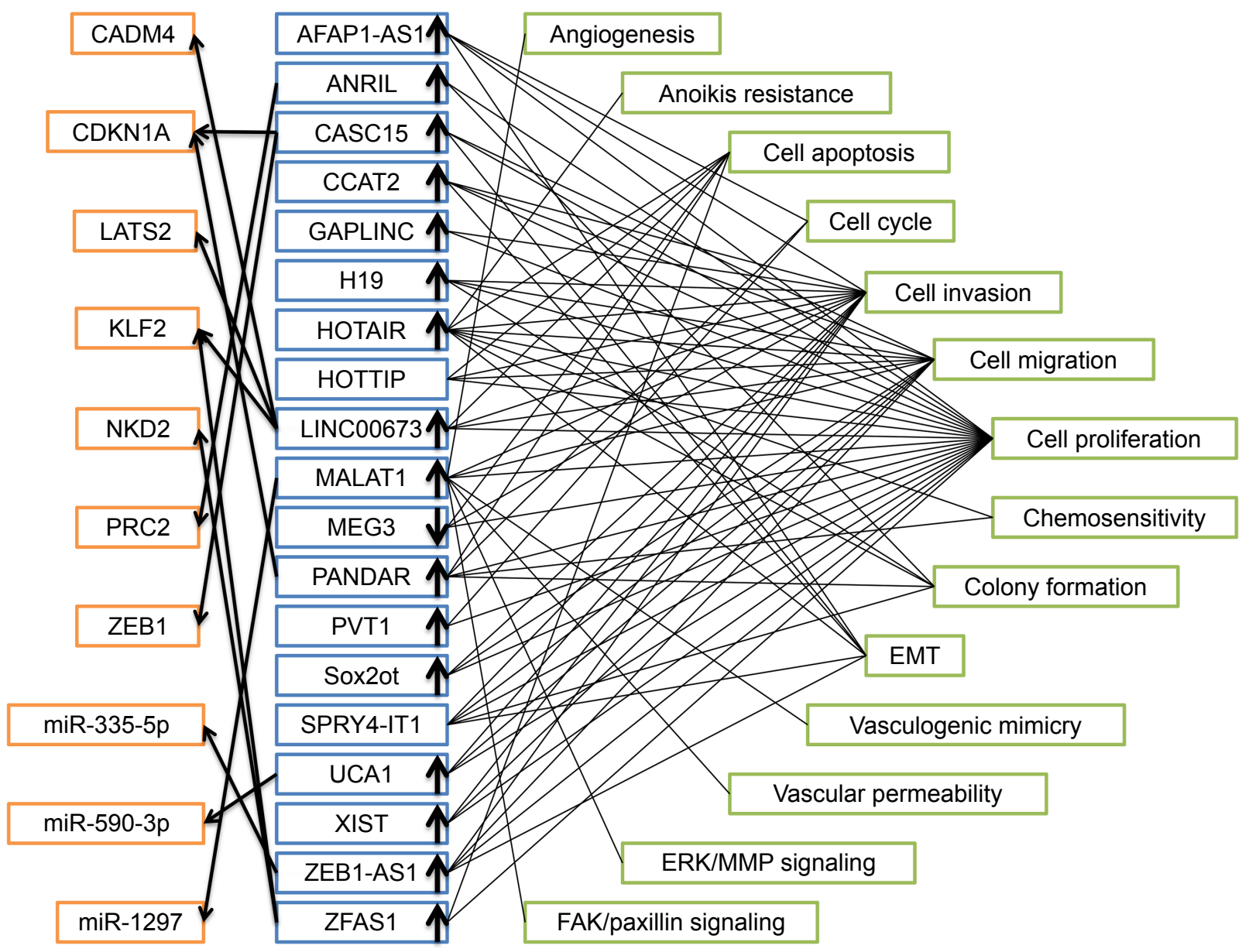

Figure 8 Summary of IncRNAs with altered expression, potential targets and pathways entered in this study.

Abbreviations: AFAPI-ASI, AFAPI antisense RNA I; ANRIL, CDKN2B antisense RNA I; CASCI5, cancer susceptibility I5; CCAT2, colon cancer associated transcript 2; EMT, epithelial-mesenchymal transition; GAPLINC, gastric adenocarcinoma associated, positive CD44 regulator, long intergenic noncoding RNA; HI9, HI9, imprinted maternally expressed transcript; HOTAIR, HOX transcript antisense RNA; HOTTIP, HOXA distal transcript antisense RNA; LINC00673, long intergenic non-protein coding RNA 673; IncRNA, long noncoding RNA; MALATI, metastasis-associated lung adenocarcinoma transcript I; MEG3, maternally expressed 3; PANDAR, promoter of CDKNIA antisense DNA damage activated RNA; PVTI, PvtI oncogene; Sox2ot, SOX2 overlapping transcript; SPRY4-ITI, SPRY4 intronic transcript I; UCAI, urothelial cancer associated I; XIST, $X$ inactive specific transcript; ZEBI-ASI, ZEBI antisense RNA I; ZFASI, ZNFXI antisense RNA I.

drafting and revising the paper and agree to be accountable for all aspects of the work.

\section{Disclosure}

The authors report no conflicts of interest in this work.

\section{References}

1. Li F, Huang C, Li Q, Wu X. Construction and comprehensive analysis for dysregulated long non-coding RNA (lncRNA)-associated competing endogenous RNA (ceRNA) network in gastric cancer. Med Sci Monit. 2018;24:37-49.

2. Chen X, Sun J, Song Y, et al. The novel long noncoding RNA AC138128.1 may be a predictive biomarker in gastric cancer. Med Oncol. 2014;31(11):262.

3. Feng Y, Zhang Q, Wang J, Liu P. Increased lncRNA AFAP1-AS1 expression predicts poor prognosis and promotes malignant phenotypes in gastric cancer. Eur Rev Med Pharmacol Sci. 2017;21(17):3842-3849.

4. Qiao CF, Zhang Y, Jin L, Du XG, Qiao ZJ. High expression of lncRNA AFAP1-AS1 promotes cell proliferation and invasion by inducing epithelial-to-mesenchymal transition in gastric cancer. Int J Clin Exp Pathol. 2017;10(1):393-400.
5. Qi F, Liu X, Wu H, et al. Long noncoding AGAP2-AS1 is activated by SP1 and promotes cell proliferation and invasion in gastric cancer. J Hematol Oncol. 2017;10(1):48.

6. Huang Y, Zhang J, Hou L, et al. LncRNA AK023391 promotes tumorigenesis and invasion of gastric cancer through activation of the PI3K/ Akt signaling pathway. J Exp Clin Cancer Res. 2017;36(1):194.

7. Fan ZY, Liu W, Yan C, et al. Identification of a five-lncRNA signature for the diagnosis and prognosis of gastric cancer. Tumour Biol. 2016; 37(10):13265-13277.

8. Yang Z, Wang R, Zhang T, Dong X. Hypoxia/lncRNA-AK123072/ EGFR pathway induced metastasis and invasion in gastric cancer. Int J Clin Exp Med. 2015;8(11):19954-19968.

9. Zhang EB, Kong R, Yin DD, et al. Long noncoding RNA ANRIL indicates a poor prognosis of gastric cancer and promotes tumor growth by epigenetically silencing of miR-99a/miR-449a. Oncotarget. 2014;5(8):2276-2292.

10. Deng W, Wang J, Zhang J, Cai J, Bai Z, Zhang Z. TET2 regulates LncRNA-ANRIL expression and inhibits the growth of human gastric cancer cells. IUBMB Life. 2016;68(5):355-364

11. Saito T, Kurashige J, Nambara S, et al. A long non-coding RNA activated by transforming growth factor- $\beta$ is an independent prognostic marker of gastric cancer. Ann Surg Oncol. 2015;22(suppl 3): S915-S922. 
12. Li L, Zhang L, Zhang Y, Zhou F. Increased expression of LncRNA BANCR is associated with clinical progression and poor prognosis in gastric cancer. Biomed Pharmacother. 2015;72:109-112.

13. Liu X, Wang Y, Sun L, et al. Long noncoding RNA BC005927 upregulates EPHB4 and promotes gastric cancer metastasis under hypoxia. Cancer Sci. 2018;109(4):988-1000.

14. Lü MH, Tang B, Zeng S, et al. Long noncoding RNA BC032469, a novel competing endogenous RNA, upregulates hTERT expression by sponging miR-1207-5p and promotes proliferation in gastric cancer. Oncogene. 2016;35(27):3524-3534.

15. Sun TT, He J, Liang Q, et al. LncRNA GClnc1 promotes gastric carcinogenesis and may act as a modular scaffold of WDR5 and KAT2A complexes to specify the histone modification pattern. Cancer Discov. 2016;6(7):784-801.

16. Wang L, Chunyan Q, Zhou Y, et al. BCAR4 increase cisplatin resistance and predicted poor survival in gastric cancer patients. Eur Rev Med Pharmacol Sci. 2017;21(18):4064-4070.

17. Zhou J, Huang H, Tong S, Huo R. Overexpression of long non-coding RNA cancer susceptibility 2 inhibits cell invasion and angiogenesis in gastric cancer. Mol Med Rep. 2017;16(4):5235-5240.

18. Yao XM, Tang JH, Zhu H, Jing Y. High expression of LncRNA CASC15 is a risk factor for gastric cancer prognosis and promote the proliferation of gastric cancer. Eur Rev Med Pharmacol Sci. 2017;21(24):5661-5667.

19. Wu Q, Xiang S, Ma J, et al. Long non-coding RNA CASC15 regulates gastric cancer cell proliferation, migration and epithelial mesenchymal transition by targeting CDKN1A and ZEB1. Mol Oncol. 2018;12(6): 799-813.

20. Liu JN, Shangguan YM. Long non-coding RNA CARLo-5 upregulation associates with poor prognosis in patients suffering gastric cancer. Eur Rev Med Pharmacol Sci. 2017;21(3):530-534.

21. Wang CY, Hua L, Yao KH, Chen JT, Zhang JJ, Hu JH. Long non-coding RNA CCAT2 is up-regulated in gastric cancer and associated with poor prognosis. Int J Clin Exp Pathol. 2015;8(1):779-785.

22. Wang YJ, Liu JZ, Lv P, Dang Y, Gao JY, Wang Y. Long non-coding RNA CCAT2 promotes gastric cancer proliferation and invasion by regulating the E-cadherin and LATS2. Am J Cancer Res. 2016;6(11): 2651-2660.

23. Pei YF, Zhang YJ, Lei Y, Wu DW, Ma TH, Liu XQ. Hypermethylation of the CHRDL1 promoter induces proliferation and metastasis by activating Akt and Erk in gastric cancer. Oncotarget. 2017;8(14): 23155-23166

24. Hao YP, Qiu JH, Zhang DB, Yu CG. Long non-coding RNA DANCR, a prognostic indicator, promotes cell growth and tumorigenicity in gastric cancer. Tumour Biol. 2017;39(6):1010428317699798.

25. Xu TP, Wang YF, Xiong WL, et al. E2F1 induces TINCR transcriptional activity and accelerates gastric cancer progression via activation of TINCR/ STAU1/CDKN2B signaling axis. Cell Death Dis. 2017;8(6):e2837.

26. Peng W, Wu J, Fan H, Lu J, Feng J. LncRNA EGOT promotes tumorigenesis Via Hedgehog Pathway in gastric cancer. Pathol Oncol Res 2017.

27. Xu TP, Huang MD, Xia R, et al. Decreased expression of the long non-coding RNA FENDRR is associated with poor prognosis in gastric cancer and FENDRR regulates gastric cancer cell metastasis by affecting fibronectin1 expression. J Hematol Oncol. 2014;7:63.

28. Wu X, Zhang P, Zhu H, Li S, Chen X, Shi L. Long noncoding RNA FEZF1-AS1 indicates a poor prognosis of gastric cancer and promotes tumorigenesis via activation of Wnt signaling pathway. Biomed Pharmacother. 2017;96:1103-1108.

29. Li CY, Liang GY, Yao WZ, et al. Integrated analysis of long non-coding RNA competing interactions reveals the potential role in progression of human gastric cancer. Int J Oncol. 2016;48(5):1965-1976.

30. Chong DQ, Shan JL, Yang CS, Wang R, Du ZM. Clinical prognostic value of A FOXM1 related long non-coding RNA expression in gastric cancer. Eur Rev Med Pharmacol Sci. 2018;22(2):417-421.

31. Feng L, Zhu Y, Zhang Y, Rao M. LncRNA GACAT3 promotes gastric cancer progression by negatively regulating miR-497 expression. Biomed Pharmacother. 2018;97:136-142.
32. Hu Y, Wang J, Qian J, et al. Long noncoding RNA GAPLINC regulates CD44-dependent cell invasiveness and associates with poor prognosis of gastric cancer. Cancer Res. 2014;74(23):6890-6902.

33. Liu L, Zhao X, Zou H, Bai R, Yang K, Tian Z. Hypoxia promotes gastric cancer malignancy partly through the HIF-1 $\alpha$ dependent transcriptional activation of the long non-coding RNA GAPLINC. Front Physiol. 2016;7:420.

34. Sun M, Jin FY, Xia R, et al. Decreased expression of long noncoding RNA GAS5 indicates a poor prognosis and promotes cell proliferation in gastric cancer. BMC Cancer. 2014;14:319.

35. Yang F, Xue X, Zheng L, et al. Long non-coding RNA GHET1 promotes gastric carcinoma cell proliferation by increasing c-Myc mRNA stability. FEBS J. 2014;281(3):802-813.

36. Li H, Yu B, Li J, et al. Overexpression of lncRNA H19 enhances carcinogenesis and metastasis of gastric cancer. Oncotarget. 2014;5(8): 2318-2329.

37. Zhang EB, Han L, Yin DD, Kong R, De W, Chen J. c-Myc-induced, long, noncoding $\mathrm{H} 19$ affects cell proliferation and predicts a poor prognosis in patients with gastric cancer. Med Oncol. 2014;31(5):914

38. Chen JS, Wang YF, Zhang XQ, et al. H19 serves as a diagnostic biomarker and up-regulation of H19 expression contributes to poor prognosis in patients with gastric cancer. Neoplasma. 2016;63(2): 223-230.

39. Chen JF, Wu P, Xia R, et al. STAT3-induced lncRNA HAGLROS overexpression contributes to the malignant progression of gastric cancer cells via mTOR signal-mediated inhibition of autophagy. Mol Cancer. 2018;17(1):6.

40. Chen WM, Huang MD, Kong R, et al. Antisense long noncoding RNA HIF1A-AS2 is upregulated in gastric cancer and associated with poor prognosis. Dig Dis Sci. 2015;60(6):1655-1662.

41. Endo H, Shiroki T, Nakagawa T, et al. Enhanced expression of long non-coding RNA HOTAIR is associated with the development of gastric cancer. PLoS One. 2013;8(10):e77070.

42. Xu ZY, Yu QM, Du YA, et al. Knockdown of long non-coding RNA HOTAIR suppresses tumor invasion and reverses epithelial-mesenchymal transition in gastric cancer. Int J Biol Sci. 2013;9(6):587-597.

43. Okugawa Y, Toiyama Y, Hur K, et al. Metastasis-associated long noncoding RNA drives gastric cancer development and promotes peritoneal metastasis. Carcinogenesis. 2014;35(12):2731-2739.

44. Liu XH, Sun M, Nie FQ, et al. Lnc RNA HOTAIR functions as a competing endogenous RNA to regulate HER 2 expression by sponging miR-331-3p in gastric cancer. Mol Cancer. 2014;13:92.

45. Zhang ZZ, Shen ZY, Shen YY, et al. HOTAIR long noncoding RNA promotes gastric cancer metastasis through suppression of poly r(C)-binding protein (PCBP) 1. Mol Cancer Ther. 2015;14(5): 1162-1170.

46. Zhao W, Dong S, Duan B, et al. HOTAIR is a predictive and prognostic biomarker for patients with advanced gastric adenocarcinoma receiving fluorouracil and platinum combination chemotherapy. Am J Transl Res. 2015;7(7):1295-1302.

47. Chen WM, Chen WD, Jiang XM, et al. HOX transcript antisense intergenic RNA represses E-cadherin expression by binding to EZH2 in gastric cancer. World J Gastroenterol. 2017;23(33):6100-6110.

48. Feng X, Huang S. Effect and mechanism of lncRNA HOTAIR on occurrence and development of gastric cancer. J Cell Biochem. 2017.

49. Li H, Li J, Zhang B, Zeng H. Long-chain non-coding RNA HOTAIR expression in tissue samples correlates with gastric cancer survival. Int J Clin Exp Med. 2018;11(2):856-862.

50. Ye H, Liu K, Qian K. Overexpression of long noncoding RNA HOTTIP promotes tumor invasion and predicts poor prognosis in gastric cancer. Onco Targets Ther. 2016;9:2081-2088.

51. Yang Y, Ma B, Yan Y, et al. Long non-coding RNA HOXA transcript at the distal tip as a biomarker for gastric cancer. Oncol Lett. 2017;14(1): 1068-1072.

52. Zhao R, Zhang Y, Zhang X, et al. Exosomal long noncoding RNA HOTTIP as potential novel diagnostic and prognostic biomarker test for gastric cancer. Mol Cancer. 2018;17(1):68. 
53. Xie M, Sun M,Zhu YN, etal. Long noncoding RNA HOXA-AS2 promotes gastric cancer proliferation by epigenetically silencing P21/PLK3/ DDIT3 expression. Oncotarget. 2015;6(32):33587-33601.

54. Sun M, Nie F, Wang Y, et al. LncRNA HOXA11-AS promotes proliferation and invasion of gastric cancer by scaffolding the chromatin modification factors PRC2, LSD1, and DNMT1. Cancer Res. 2016;76(21): 6299-6310.

55. Ma B, Wang J, Song Y, et al. Upregulated long intergenic noncoding RNA KRT18P55 acts as a novel biomarker for the progression of intestinal-type gastric cancer. Onco Targets Ther. 2016;9:445-453.

56. Zhou B, Jing XY, Wu JQ, Xi HF, Lu GJ. Down-regulation of long noncoding RNA LET is associated with poor prognosis in gastric cancer. Int J Clin Exp Pathol. 2014;7(12):8893-8898.

57. Shan Y, Ying R, Jia Z, et al. LINC00052 promotes gastric cancer cell proliferation and metastasis via activating the Wnt/ $\beta$-catenin signaling pathway. Oncol Res. 2017;25(9):1589-1599.

58. Chen WM, Huang MD, Sun DP, et al. Long intergenic non-coding RNA 00152 promotes tumor cell cycle progression by binding to EZH2 and repressing p15 and p21 in gastric cancer. Oncotarget. 2016;7(9): 9773-9787.

59. Zhang ZZ, Zhao G, Zhuang C, et al. Long non-coding RNA LINC00628 functions as a gastric cancer suppressor via long-range modulating the expression of cell cycle related genes. Sci Rep. 2016;6:27435.

60. Zhang E, Yin D, Han L, et al. E2F1-induced upregulation of long noncoding RNA LINC00668 predicts a poor prognosis of gastric cancer and promotes cell proliferation through epigenetically silencing of CKIs. Oncotarget. 2016;7(17):23212-23226.

61. Ba MC, Long H, Cui SZ, et al. Long noncoding RNA LINC00673 epigenetically suppresses KLF4 by interacting with EZH2 and DNMT1 in gastric cancer. Oncotarget. 2017;8(56):95542-95553.

62. Huang M, Hou J, Wang Y, et al. Long noncoding RNA LINC00673 is activated by SP1 and exerts oncogenic properties by interacting with LSD1 and EZH2 in gastric cancer. Mol Ther. 2017;25(4):1014-1026.

63. Zeng S, Xie X, Xiao YF, et al. Long noncoding RNA LINC00675 enhances phosphorylation of vimentin on Ser83 to suppress gastric cancer progression. Cancer Lett. 2018;412:179-187.

64. Fei ZH, Yu XJ, Zhou M, Su HF, Zheng Z, Xie CY. Upregulated expression of long non-coding RNA LINC00982 regulates cell proliferation and its clinical relevance in patients with gastric cancer. Tumour Biol. 2016;37(2):1983-1993.

65. Miao Y, Sui J, Xu SY, Liang GY, Pu YP, Yin LH. Comprehensive analysis of a novel four-lncRNA signature as a prognostic biomarker for human gastric cancer. Oncotarget. 2017;8(43):75007-75024.

66. Chen X, Chen Z, Yu S, et al. Long noncoding RNA LINC01234 functions as a competing endogenous RNA to regulate CBFB expression by sponging miR-204-5p in gastric cancer. Clin Cancer Res. 2018;24(8): 2002-2014.

67. Qin QH, Yin ZQ, Li Y, Wang BG, Zhang MF. Long intergenic noncoding RNA 01296 aggravates gastric cancer cells progress through miR-122/MMP-9. Biomed Pharmacother. 2018;97:450-457.

68. Zou Z, Ding Q, Li P, et al. Overexpression of lincRNA-ROR predicts poor prognosis in patients with gastric cancer. Int J Clin Exp Pathol. 2016;9(9):9467-9472.

69. Hu Y, Pan J, Wang Y, Li L, Huang Y. Long noncoding RNA linc-UBC1 is negative prognostic factor and exhibits tumor pro-oncogenic activity in gastric cancer. Int J Clin Exp Pathol. 2015;8(1):594-600.

70. Guo W, Dong Z, Shi Y, et al. Methylation-mediated downregulation of long noncoding RNA LOC100130476 in gastric cardia adenocarcinoma. Clin Exp Metastasis. 2016;33(5):497-508.

71. Zhao Y, Liu Y, Lin L, et al. The lncRNA MACC1-AS1 promotes gastric cancer cell metabolic plasticity via AMPK/Lin28 mediated mRNA stability of MACC1. Mol Cancer. 2018;17(1):69.

72. Qi Y, Ooi HS, Wu J, et al. MALAT1 long ncRNA promotes gastric cancer metastasis by suppressing PCDH10. Oncotarget. 2016;7(11): 12693-12703.

73. Li J, Gao J, Tian W, Li Y, Zhang J. Long non-coding RNA MALAT1 drives gastric cancer progression by regulating HMGB2 modulating the miR-1297. Cancer Cell Int. 2017;17:44.
74. Li Y, Wu Z, Yuan J, et al. Long non-coding RNA MALAT1 promotes gastric cancer tumorigenicity and metastasis by regulating vasculogenic mimicry and angiogenesis. Cancer Lett. 2017;395:31-44.

75. Chen F, Tian Y, Pang EJ, Wang Y, Li L. MALAT2-activated long noncoding RNA indicates a biomarker of poor prognosis in gastric cancer. Cancer Gene Ther. 2015.

76. Sun M, Xia R, Jin F, et al. Downregulated long noncoding RNA MEG3 is associated with poor prognosis and promotes cell proliferation in gastric cancer. Tumour Biol. 2014;35(2):1065-1073.

77. Guo W, Dong Z, Liu S, et al. Promoter hypermethylation-mediated downregulation of miR-770 and its host gene MEG3, a long noncoding RNA, in the development of gastric cardia adenocarcinoma. Mol Carcinog. 2017;56(8):1924-1934.

78. Nie FQ, Ma S, Xie M, Liu YW, De W, Liu XH. Decreased long noncoding RNA MIR31HG is correlated with poor prognosis and contributes to cell proliferation in gastric cancer. Tumour Biol. 2016;37(6): 7693-7701.

79. Quan Y, Zhang Y, Lin W, et al. Knockdown of long non-coding RNA MAP3K20 antisense RNA 1 inhibits gastric cancer growth through epigenetically regulating miR-375. Biochem Biophys Res Commun. 2018;497(2):527-534.

80. Lai Y, Xu P, Liu J, et al. Decreased expression of the long non-coding RNA MLLT4 antisense RNA 1 is a potential biomarker and an indicator of a poor prognosis for gastric cancer. Oncol Lett. 2017;14(3):2629-2634.

81. Wang Y, Zhang D, Wu K, Zhao Q, Nie Y, Fan D. Long noncoding RNA MRUL promotes ABCB1 expression in multidrug-resistant gastric cancer cell sublines. Mol Cell Biol. 2014;34(17):3182-3193.

82. Lin Z, Lai S, He X, et al. Decreased long non-coding RNA MTM contributes to gastric cancer cell migration and invasion via modulating MT1F. Oncotarget. 2017;8(57):97371-97383.

83. Fu JW, Kong Y, Sun X. Long noncoding RNA NEAT1 is an unfavorable prognostic factor and regulates migration and invasion in gastric cancer. J Cancer Res Clin Oncol. 2016;142(7):1571-1579.

84. Guo X, Yang Z, Zhi Q, et al. Long noncoding RNA OR3A4 promotes metastasis and tumorigenicity in gastric cancer. Oncotarget. 2016;7(21): 30276-30294

85. Wang YQ, Zhang QY, Weng WW, et al. Upregulation of the non-coding RNA OTUB1-isoform 2 contributes to gastric cancer cell proliferation and invasion and predicts poor gastric cancer prognosis. Int J Biol Sci. 2016;12(5):545-557.

86. MaP, Xu T, Huang M, Shu Y. Increased expression of LncRNA PANDAR predicts a poor prognosis in gastric cancer. Biomed Pharmacother. 2016;78:172-176.

87. Liu J, Ben Q, Lu E, et al. Long noncoding RNA PANDAR blocks CDKN1A gene transcription by competitive interaction with $\mathrm{p} 53$ protein in gastric cancer. Cell Death Dis. 2018;9(2):168.

88. Bi M, Yu H, Huang B, Tang C. Long non-coding RNA PCAT-1 overexpression promotes proliferation and metastasis in gastric cancer cells through regulating CDKN1A. Gene. 2017;626:337-343.

89. Kong R, Zhang EB, Yin DD, et al. Long noncoding RNA PVT1 indicates a poor prognosis of gastric cancer and promotes cell proliferation through epigenetically regulating p15 and p16. Mol Cancer. 2015;14:82.

90. Yuan CL, Li H, Zhu L, Liu Z, Zhou J, Shu Y. Aberrant expression of long noncoding RNA PVT1 and its diagnostic and prognostic significance in patients with gastric cancer. Neoplasma. 2016;63(3):442-449.

91. Sun J, Song Y, Chen X, et al. Novel long non-coding RNA RP11119 F7.4 as a potential biomarker for the development and progression of gastric cancer. Oncol Lett. 2015;10(1):115-120.

92. Song W, Liu YY, Peng JJ, et al. Identification of differentially expressed signatures of long non-coding RNAs associated with different metastatic potentials in gastric cancer. $J$ Gastroenterol. 2016;51(2):119-129.

93. Hu Y, Ma Z, He Y, Liu W, Su Y, Tang Z. LncRNA-SNHG1 contributes to gastric cancer cell proliferation by regulating DNMT1. Biochem Biophys Res Commun. 2017;491(4):926-931.

94. Yan K, Tian J, Shi W, Xia H, Zhu Y. LncRNA SNHG6 is associated with poor prognosis of gastric cancer and promotes cell proliferation and EMT through epigenetically silencing p27 and sponging miR-101-3p. Cell Physiol Biochem. 2017;42(3):999-1012. 
95. Zhang H, Lu W. LncRNA SNHG12 regulates gastric cancer progression by acting as a molecular sponge of miR-320. Mol Med Rep. 2018; 17(2):2743-2749.

96. Zhang Y, Yang R, Lian J, Xu H. LncRNA Sox2ot overexpression serves as a poor prognostic biomarker in gastric cancer. Am J Transl Res. 2016;8(11):5035-5043.

97. Zou JH, Li CY, Bao J, Zheng GQ. High expression of long noncoding RNA Sox2ot is associated with the aggressive progression and poor outcome of gastric cancer. Eur Rev Med Pharmacol Sci. 2016;20(21): $4482-4486$.

98. Peng W, Wu G, Fan H, Wu J, Feng J. Long noncoding RNA SPRY4IT1 predicts poor patient prognosis and promotes tumorigenesis in gastric cancer. Tumour Biol. 2015;36(9):6751-6758.

99. Xie M, Nie FQ, Sun M, et al. Decreased long noncoding RNA SPRY4IT1 contributing to gastric cancer cell metastasis partly via affecting epithelial-mesenchymal transition. J Transl Med. 2015;13:250.

100. Zhang E, He X, Yin D, et al. Increased expression of long noncoding RNA TUG1 predicts a poor prognosis of gastric cancer and regulates cell proliferation by epigenetically silencing of p57. Cell Death Dis. 2016;7:e2109.

101. Zheng Q, Wu F, Dai WY, et al. Aberrant expression of UCA1 in gastric cancer and its clinical significance. Clin Transl Oncol. 2015; 17(8):640-646.

102. Nasrollahzadeh-Khakiani M, Emadi-Baygi M, Nikpour P. Augmented expression levels of lncRNAs ecCEBPA and UCA1 in gastric cancer tissues and their clinical significance. Iran J Basic Med Sci. 2017;20(10):1149-1158.

103. Zuo ZK, Gong Y, Chen XH, et al. TGF $\beta 1$-induced LncRNA UCA1 upregulation promotes gastric cancer invasion and migration. DNA Cell Biol. 2017;36(2):159-167.

104. Gu L, Lu LS, Zhou DL, Liu ZC. UCA1 promotes cell proliferation and invasion of gastric cancer by targeting CREB1 sponging to miR-590-3p. Cancer Med. 2018;7(4):1253-1263.

105. Chen M, Wu X, Ma W, et al. Decreased expression of IncRNA VPS9D1AS1 in gastric cancer and its clinical significance. Cancer Biomark. 2017;21(1):23-28.

106. Cai J, Wang D, Bai ZG, Yin J, Zhang J, Zhang ZT. The long noncoding RNA XIAP-AS1 promotes XIAP transcription by XIAP-AS1 interacting with Sp1 in gastric cancer cells. PLoS One. 2017;12(8): e0182433.

107. Chen DL, Ju HQ, Lu YX, et al. Long non-coding RNA XIST regulates gastric cancer progression by acting as a molecular sponge of miR-101 to modulate EZH2 expression. J Exp Clin Cancer Res. 2016;35(1):142.

108. Ma L, Zhou Y, Luo X, Gao H, Deng X, Jiang Y. Long non-coding RNA XIST promotes cell growth and invasion through regulating miR-497/ MACC1 axis in gastric cancer. Oncotarget. 2017;8(3):4125-4135.
109. Li Y, Wen X, Wang L, et al. LncRNA ZEB1-AS1 predicts unfavorable prognosis in gastric cancer. Surg Oncol. 2017;26(4):527-534.

110. Zhang LL, Zhang LF, Guo XH, Zhang DZ, Yang F, Fan YY. Downregulation of miR-335-5p by long noncoding RNA ZEB1AS1 in gastric cancer promotes tumor proliferation and invasion. DNA Cell Biol. 2018;37(1):46-52.

111. Zhang JJ, Chen JT, Yao KH, Hua L, Wang CY, Hu JH. Up-regulated expression of long non-coding RNA ZFAS1 associates with aggressive tumor progression and poor prognosis in gastric cancer patients Int J Clin Exp Pathol. 2016;9(2):2059-2063.

112. Nie F, Yu X, Huang M, et al. Long noncoding RNA ZFAS1 promotes gastric cancer cells proliferation by epigenetically repressing KLF2 and NKD2 expression. Oncotarget. 2017;8(24):38227-38238.

113. Lai Y, Xu P, Li Q, et al. Downregulation of long noncoding RNA ZMAT1 transcript variant 2 predicts a poor prognosis in patients with gastric cancer. Int J Clin Exp Pathol. 2015;8(5):5556-5562.

114. McLean MH, El-Omar EM. Genetics of gastric cancer. Nat Rev Gastroenterol Hepatol. 2014;11(11):664-674.

115. Torre LA, Bray F, Siegel RL, Ferlay J, Lortet-Tieulent J, Jemal A. Global cancer statistics, 2012. CA Cancer J Clin. 2015;65(2):87-108.

116. Siegel RL, Miller KD, Jemal A. Cancer statistics, 2015. CA Cancer J Clin. 2015;65(1):5-29.

117. GBD 2013 Mortality and Causes of Death Collaborators. Global, regional, and national age-sex specific all-cause and cause-specific mortality for 240 causes of death, 1990-2013: a systematic analysis for the Global Burden of Disease Study 2013. Lancet. 2015;385(9963): 117-171.

118. Ponting CP, Oliver PL, Reik W. Evolution and functions of long noncoding RNAs. Cell. 2009;136(4):629-641.

119. Cheetham SW, Gruhl F, Mattick JS, Dinger ME. Long noncoding RNAs and the genetics of cancer. Br J Cancer. 2013;108(12):2419-2425.

120. Spizzo R, Almeida MI, Colombatti A, Calin GA. Long non-coding RNAs and cancer: a new frontier of translational research? Oncogene. 2012;31(43):4577-4587

121. Li T, Mo X, Fu L, Xiao B, Guo J. Molecular mechanisms of long noncoding RNAs on gastric cancer. Oncotarget. 2016;7(8):8601-8612.

122. Parmar MK, Torri V, Stewart L. Extracting summary statistics to perform meta-analyses of the published literature for survival endpoints. Stat Med. 1998;17(24):2815-2834

123. Xu MD, Qi P, Weng WW, et al. Long non-coding RNA LSINCT5 predicts negative prognosis and exhibits oncogenic activity in gastric cancer. Medicine (Baltimore). 2014;93(28):e303.

124. Dan J, Wang J, Wang Y, et al. LncRNA-MEG3 inhibits proliferation and metastasis by regulating miRNA-21 in gastric cancer. Biomed Pharmacother. 2018;99:931-938.
OncoTargets and Therapy

\section{Publish your work in this journal}

OncoTargets and Therapy is an international, peer-reviewed, open access journal focusing on the pathological basis of all cancers, potential targets for therapy and treatment protocols employed to improve the management of cancer patients. The journal also focuses on the impact of management programs and new therapeutic agents and protocols on

\section{Dovepress}

patient perspectives such as quality of life, adherence and satisfaction. The manuscript management system is completely online and includes a very quick and fair peer-review system, which is all easy to use. Visit http://www.dovepress.com/testimonials.php to read real quotes from published authors. 